\title{
DUKUNGAN KELUARGA BERHUBUNGAN DENGAN KEPATUHAN MINUM OBAT PADA PASIEN TUBERKULOSIS PARU
}

\author{
Mulidan*, Dedi, Muhammad Khadafi \\ D3 Keperawatan, Institut Kesehatan Helvetia, Jln.Sumarsono No. 107, Helvetia, Kec Sunggal, Kabupaten \\ Deli Serdang, Sumatera Utara 20124, Indonesia \\ *mulidan22@gmail.com (+6281377248405)
}

\begin{abstract}
ABSTRAK
Penderita Tuberculosis paru setiap tahun mengalami peningkatan, hal tersebut disebabkan oleh beberapa faktor pencetus seperti putus obat,kurangnya dukungan keluarga dan ketidakpatuhan pasien minum obat secara teratur, pada penderita tuberculosis paru dukungan keluarga sangat dibutuhkan dalam meningkatkan motivasi pasien patuh minum obat secara teratur untuk meningkatkan kesembuhan. Tujuan penelitian dilakukan untuk diketahui keterkaitan dukungan keluarga dalam memantau kepatuhan pasien minum obat. Metode yang digunakan yaitu Survei Analitik dengan menggunakan metode Cross sectional dengan uji chi-square. Populasi penelitian yaitu responden penderita tuberkulosis Paru berjumlah 173 responden. Pengambilan sample yang digunakan adalah Accidental sampling, pengambilan sampel menggunakan instrument atau alat ukur yaitu kuesioner dengan tekhnik Slovin yang berjumlah 63 responden.Berdasarkan hasil analisa dengan menggunakan Uji Chi-Square Test memperlihatkan bahwa nilai $\mathrm{p}=0,010<\alpha=0,05$, hal ini membuktikan dukungan keluarga berhubungan dengan tingkat kepatuhan pasien minum obat tuberculosis paru.Kesimpulan dalam penelitian ini secara statistik bahwa dukungan keluarga saling berhubungan dnegan tingkat kepatuhan pasien minum obat secara teratur.
\end{abstract}

Kata kunci: dukungan keluarga; kepatuhan minum obat; tingkat dukungan; tuberkulosis paru

\section{FAMILY SUPPORT RELATED WITH MEDICATION ADHERENCE IN PATIENT OF PULMONARY TUBERCULOSIS}

\begin{abstract}
Pulmonary tuberculosis sufferers have increased every year, this is caused by several precipitating factors such as drug with drawal, lack of family support and non-adherence to patients taking medication regularly. The study aimed to determine the relationship between family support in monitoring patient compliance with medication. The design used was an Analytical Survey used Cross-sectional method with chi-square test. The population were patient with Pulmonary Tuberculosis amounted to 173 respondent. The sampling used is accidental sampling,sampling using the instrument or the measuring instrument was a questionnaire with techniques Slovin which amounts to 63 respondents. Based on the results of the analysis using the Test Chi-Square Test showed that the value of $p=.010<a=.05$. This proves that family support is related to the level of compliance of patients taking pulmonary tuberculosis drugs. Conclusion in this study is statistically that family support is related to the level of patient adherence to taking medication regularly.
\end{abstract}

Keywords: family support; complience with medication; level of support; pulmonary tuberculosis 


\section{PENDAHULUAN}

Tuberkulosis (TB) merupakan penyakit menular sebagai penyebab utama masalah kesehatan. Penyakit tuberculosis penyebab kematian peringkat 10 di dunia,penyakit ini disebabkan oleh bakteri Mycobacterium Tuberculosis. Mayoritas penduduk dunia terinfeksi penyakit tuberculosis,pencegahan dan penyembuhan yang dapat dilakukan berdasarkan peraturan yang ditetapkan World Health Organization dengan rutin minum obat anti tuberculosis paru dengan program 6 bulan awal dapat disembuhkan terbukti mengalami penurun angka kejadian infeksi (WHO, 2019).

Penderita tuberkulosis di Sumatera Utara berjumlah 26.361 kasus dengan proporsi sebesar $0,18 \%$ tahun 2017 , dengan jumlah kasus terbanyak adalah Kota Medan 8.192 kasus dengan proporsi sebesar $1,8 \%$ diikuti dengan Deli Serdang sebanyak 3.204 kasus (0,15\%). Angka Success Rate tuberkulosis menurut Kabupaten/Kota Provinsi Sumetera Utara Tahun 2017 tidka mencapai target yaitu $85 \%$ dimana kota medan 84,11 \%,Nias $83,9 \%$,sidempuan $\quad(79,47 \%)$,binjai $(72,03 \%)$,dan simalungun $(63,22 \%)$ angka Success Rate. (DinKes Sumut, 2018)

Jumlah kasus baru atau jumlah kejadian insiden Tuberkulosis paru di Indonesia tahun 2016 sebesar 298.128 kasus. BTA positif ditemukan sebesar 156.723 kasus diantaranya $39 \%$ perempuan dan $61 \%$ laki-laki dimana $1 \%$ anak-anak dan $99 \%$ dewasa. Menurut Case Notification Rate (CNR) atau angka notifikasi kasus, jumlah penderita tuburkulosis positif mencapai $60 \%$ dan . Case Detection Rate (CDR) atau angka penemuan kasus, presentase jumlah psien baru BTA positif yang dtemukan 60,59 15 dan telah diobati dengan program pengobatan tuberkulosis (Kemenkes RI, 2017).

Pada tahun 2018 angka kasus penderita tuberkulosi paru di Kota Medan sebesar 1.196 kasus. Tingkat kesembuhan (cute rate) tuberculosis paru di Kota Medan sebesar 88,2\%, Angka pengobatan lengkap sebesar $37,6 \%$ dan tingkat keberhasilan pengobatan yang dilakukan (success rate) sebesar 91,1\% (Dinas Kesehatan Kota Medan, 2018).

Tuberkulosis biasanya menyerang bagian paru-paru, yang kemudian dapat menyerang kesemua bagian tubuh. Infeksi biasanya terjadi 2-10 minggu. Pasca 10 minggu, klien akan muncul manifestasi penyakit karena gangguan dan ketidakefektifan respon imun. Proses aktivasi dapat berkepanjangan dan ditandai dengan remisi panjang ketika penyakit dicegah, hanya untuk diikuti oleh priode aktivitas yang diperbarui (Puspasari, 2017)

Proses penyebaran tuberculosis ketika pasien batuk atau bersin, sehingga droplet akan menyebar ke udara yang mengandung bateri tuberkulosis. Meskipun tuberculosis menyebar dengan cara yang sama dengan flu, penyakit ini tidak menular dengan mudah. Seseorang harus kontak dalam waktu beberapa jam dengan orang yang terinfeksi diperbarui (Puspasari, 2017). Pada umunya pasien tuberculosis akan timbul gejala berpariasi, mulai dari batuk, batuk darah, nyeri dada, badan lemah dan lain-lain. Batuk terjadi karena adanya iritasi disaluran nafas, dan selanjutnya batuk diperlukan untuk membuang dahak keluar. Batuk darah dapat terjadi bila ada pembuluh darah yang terkena dan kemudian pecah. diperbarui (Aditama, 2017). 
Komplikasi yang terjadi pada pasien tuberculosis paru jika tidak tertanggani dengan tepat seperti kerusakan sendi (atritis),infeksi pada meningen,nyeri tulang belakang,gagal ginjal dan gangguan pada jantung (Puspasari, 2017). Pada pasien tuberculosis motivasi atau support keluarga sangat dibutuhkan dalam menjalani program pengobatan pada fase intensif. Pasien mudah bosan dan putus asa menjalani pngobatan yang beresiko putus obat hal ini dapat memperburuk kondisi pasien. (Rumimpunu, 2017).

Kepatuhan paisen mengkonsumsi obat secara teratur sesuai dnegan program pengobatan hal penting yang harus dipatuhi pasien, obat tuberculosis termasuk kedalam obat antibiotic yang dapat menimbulkan efek samping jika tidak diminum secara teratur (Afiani D, 2012). Kepatuhan pemakaian obat tuberkulosis menjadi indikator penting karena bila pengobatan tidak dilakukan secara teratur, tidak sesuai dengan waktu pengobatan, dan penggunaan obat tidak adekuat akan menimbulkan resistensi terhadap OAT atau yang disebut dengan Multi Drugs Resistence (MDR) (Tristiyana, TS. 2020)

\section{World Health Organization (WHO)} telah merekomendasikan upaya diagnosis melalui pemeriksaan dahak langsung dan pengobatan menggunakan obat anti tuberkulosis serta metode pengobatan pasien dengan pola rawat jalan pada tahun 1977 mulai diperkenalkan pengobatan jangka pendek ( 6 bulan) dengan menggunakan panduan Obat Anti Tuberkulosis (OAT) (WHO, 2017).

Kegagalan pada pasien tuberkulosis paru dalam menjalani pengobatan dikarenakan tingkat kepatuhan pasien minum obat menurun hal ini dipengaruhi beberapa faktor salah satunya pasien bosan dan tidak ada motivasi untuk minum obat secara teratur teratur sesuai indikasi, hal ini yang menyebabkan pasien berhenti minum obat tampa konsultasi dnegan dokter (Pitters, 2019). Berdasarkan penelitian yang telah dilakukan Jeini, E. (2018) menyatakan pasien tuberculosis paru patuh terhadap minum obat dan memiliki dukungan keluarga 74,2\% ,sedangkan pasien yang patuh namun dukungan keluarganya kurang 25,8\%. Pasien yang tidak patuh minum obat tapi mendapatkan dukungan dukungan $11,8 \%$ sedangkan yang tidak patuh namun dukungan keluarganya kurang yaitu $88,2 \%$.

Kepatuhan minum obat oleh pasien Tuberculosis paru merupakan kelanjutan intervensi terapi yang harus dilaksanakan oleh pasien sehingga dapat mendukung kesembuhan yang optimal. (Notoatmojo, 2013). Dukungan keluarga dapat meningkatakan motivasi dan kesembuhan bagi pasien tuberculosis dalam menjalani program pengobatan 6 bulan. Berdasarkan survey tempat penelitian didapatkan data tahun 2019 kasus tuberkulosis paru berjumlah 173 orang dan peneliti melakukan wawancara beberapa pasien pasien Tuberkulosis paru 3 di antara 8 pasien menyatakan dukungan keluarga sangat penting bagi merka untuk memotivasi meraka dalam minum obat dan yang lain tidak mendapatkan dukungan keluarga. Berdasarkan fenomena tersebut yang terjadi di Rumah Sakit, peneliti ingin meneliti tentang apakah dukungan keluarga berhubungang dnegan tingkat kepatuhan pasien tuberculosis dalam minum obat sesuai dnegan program pengobatan. 


\section{METODE}

Desain yang digunakan dalam penelitian dengan desian survey analitik dengan menggunakan metode Crosssectional dengan uji Chi-square. Sampel dalam penelitian ini pasien yang mengalami tuberculosis postif berjumlah 63 orang responden dari populasi 173 responden yang menderita tuberkulosis paru. Pengambilan sampel menggunakan teknik Acidental Sampling dimana pengambilan sampel secara kebetulan tampa direncanakan.

Insturmen dalam penelitian berupa kuesioner yang telah diuji validitas dan reliabilitsnya dengan hasil nilai alpha cronbach 0,934 dan nilai reliablitas 0,8 $>0,7$. Teknik analisa data menggunakan uji statistik yaitu Uji Chi- Square dengan nilai $p(0,5)$ jika hasil $p<0,5$ maka Ho ditolak Ha diterima artinya terdapat hubungan anatar varibel. Pengisian kuesioner dilakukan oleh masing-masing responden dan didampingi oleh peneliti.

\section{HASIL}

\section{Karakteristik Responden}

Tabel 1, hasil distribusi frekuensi karakteristik responden mayoritas berjenis laki-laki 41 responden $(65,1 \%)$ dari 63 responden,sedangkan dari jenjang pendidikan mayoritas responden berpendidikan SD 39 (61,9\%) dan dari status pekerjaan mayoritas responden sebagai pekerja swasta 22 responden $(34,9 \%)$ dari 63 responden.

Tabel 2 distribusi frequensi mayoritas dukungan keluarga pada pasien tuberculosis paru yang tidak mendukung sebanyak 35 orang $(55,6 \%)$, dan yang mendukung sebanyak 28 orang $(44,4 \%)$. Artinya mayoritas keluarga tidak mendukung/memberi motivasi pengobatan tuberculosis.

Table 1.

Karakteristik Responden ( $\mathrm{n}=63)$

\begin{tabular}{lcc}
\hline \multicolumn{1}{c}{ Karakteristik } & $\mathrm{f}$ & $\%$ \\
\hline Jenis Kelamin & & \\
$\quad$ Laki-laki & 41 & 65,1 \\
Perempuan & 22 & 34,9 \\
Pendidikan & & \\
$\quad$ SD & 39 & 61,9 \\
SMP & 21 & 33,3 \\
SMA & 2 & 3,2 \\
Sarjana & 1 & 1,6 \\
Pekerjaan & & \\
Ibu Rumah Tangga & 14 & 22,2 \\
Karyawan Swasta & 22 & 34,9 \\
Petani & 5 & 7,9 \\
Pegawai Negeri & 1 & 1,6 \\
Lain-Lain & 21 & 33,3 \\
\hline
\end{tabular}

Tabel 2.

Dukungan Keluarga $(n=63)$

\begin{tabular}{ccc}
\hline Dukungan Keluarga & $\mathrm{f}$ & $\%$ \\
\hline Tidak mendukung & 35 & 55,6 \\
\hline Mendukung & 28 & 44,4 \\
\hline
\end{tabular}


Tabel. 3 distribusi frekuensi terkait kepatuhan pasien minum obat yang tidak patuh 28 responden $(44,4 \%)$, dan Kepatuhan Minum Obat pada yang patuh 35 responden $(56,6 \%)$. Dapat disimpulkan mayoritas pasien patuh minum obat.

Tabel 3.

Kepatuhan Minum Obat

\begin{tabular}{ccc}
\hline Kepatuhan Minum Obat & \multicolumn{2}{c}{ Jumlah } \\
\cline { 2 - 3 } & $\mathrm{f}$ & $\%$ \\
\hline Tidak Patuh & 28 & 44,4 \\
\hline Patuh & 35 & 56,6 \\
\hline Total & 63 & 100, \\
\hline
\end{tabular}

Tabel 4

Tabulasi silang dukungan keluarga patuh minum obat tuberkulosis $(n=63)$

\begin{tabular}{|c|c|c|c|c|c|c|c|}
\hline \multirow{3}{*}{$\begin{array}{c}\text { Dukungan } \\
\text { Keluarga }\end{array}$} & \multicolumn{6}{|c|}{ Kepatuhan Minum Obat } & \multirow{3}{*}{$\begin{array}{c}\text { Asyim } \\
\text { sing }\end{array}$} \\
\hline & \multicolumn{2}{|c|}{ Tidak Patuh } & \multicolumn{2}{|c|}{ Patuh } & \multicolumn{2}{|c|}{ Total } & \\
\hline & $\mathrm{f}$ & $\%$ & $f$ & $\%$ & $\mathrm{f}$ & $\%$ & \\
\hline Tidak Mendukung & 21 & 33,3 & 14 & 22,2 & 35 & 55,6 & 010 \\
\hline Mendukung & 7 & 11,1 & 21 & 33,3 & 28 & 44,4 & 0,010 \\
\hline
\end{tabular}

Tabel 4 dapat dilihat hasil tabulasi silang keterkaitan dukungan keluarga terhadap tingkat kepatuhan pasien minum obat secara teratur pada sampel 63 responden $(100,0 \%)$, didapati bahwa dukungan keluarga yang tidak mendukung tidak patuh minum obat 21 responden $(33,3 \%)$, sedangkan dukungan keluarga tidak mendukung patuh minum obat 14 reponden $(22,2 \%)$ dan dukungan keluarga mendukung dengan tidak patuh minum obat sebanyak 7 responden $(11,1 \%)$, sedangkan dukungan keluarga mendukung pasien patuh minum obat 35 responden $(33,3 \%)$.

Tabel 4 hasil dari Uji Chi-Square didapatkan nilai $p=0,010$ dan nilai $\alpha=$ 0,05, maka Ha diterima dan $\mathrm{H}_{0}$ ditolak dapat disimpulkan ada keterkaitan dukungan keluarga dengan tingkat kepatuhan pasien tuberkulosis minum obat. Dukungan keluarga dapat memberikan motivasi dan kepercayaan diri pasien dalam menjalani pengobatan dan tingkat kepatuhan pasien minum obat teratur dna terjadwal.

\section{PEMBAHASAN}

\section{Karakteristik Responden}

Berdasarkan hasil penelitian didapatkan bahwa karakteristik responden mayoritas berjenis kelamin laki-laki $41(65,1 \%)$ responden dari 63 responden daripada perempuan,sedangkan dari segi pekerjaan mayoritas pekerja swasta. Terdapat beberapa faktor penderita lebih banyak laki-laki hal ini dipengaruhi oleh pola hidup dan dukungan keluarga pada penderita selama menjalani pengobatan.

\section{Dukungan Keluarga}

Berdasarkan pengamatan dan hasil statistik peneliti mendapatkan bahwa tingkat kepatuhan pasien tuberculosis minum obat secara teratur mempunyai keterkaitan dengan dukungan keluarga dalam memotivasi dan memantau 
paisen minum obat. Hal ini dialami beberapa pasien yang menjadi sampel penelitian didapatkan pasien tidak patuh minum obat akibat keluarga kurang peduli dan mengakibatkan pasien ptus asa dengan menghentikan pengobatan secara individual.

Adanya dukungan keluarga dalam memantau tingkat kepatuhan pasien minum obat akan meningkatkan motivasi pasien patuh minum obat dan hal ini akan menjadi indikator tingkat keberhasilan pencapaian kesembuhan pasien. Berdasarkan penelitian yang dilakukan oleh Lestasri, T. (2020) menyatakan peran dan dukungan keluarga sangat berhubungan dalam meningkatkan tingkat kepatuhan pasien minum obat hal ini dibuktikan hasil dari Spearman Rank $\mathrm{p}=0,042<0,05$.

Hasil penelitian yang dilakukan di Rumah Sakit menunjukkan bahwa dari 63 responden dukungan keluarga pada pasien tuberculosis paru yang tidak mendukung sebanyak 35 responden $(55,6 \%)$, dan keluarga yang mendukung 28 responden $(44,4 \%)$. Hasil penelitian ini sejalan dengan penelitian yang dilakukan Sunarmi, (2020) tentang dukungan keluarga dengan kepatuhan pasien dalam pengobatan menyatakan bahwa pentingnya support yang diberikan keluarga pada penderita yang mengalami TB paru hal ini akan menumbuhkan kepercayaan diri dan motivasi pasien untuk sembuh, terdapat hubungan yang signifikan dari hasil uji chi-square $p=0,007$.

Penelitian yang dilakukan Rosa (2019) juga menyatakan tingkat dukungan keluarga dalam memantau pengobatan pada pasien tuberkulosis paru sangat berpengaruh dari 63 reponden terdapat $60,9 \%$ mendapat dukungan yang baik dan responden yang patuh $73,9 \%$.
Penelitian Hendes (2017) dengan judul hubungan pengetahuan, sikap, dukungan keluarga dengan kepatuhan berobat pada pasien tuberkulosis paru. Menyatakan dari 62 responden terdapat 24 responden $(38,7 \%)$ yang dukungan keluarganya kurang baik dan 38 reponden $(61,3 \%)$ yang dukungan keluarganya baik. Dapat disimpulkan bahwa keluarga yang tidak mendukung sebanyak 35 reponden $(55,6 \%)$ dari 63 sampel, hal ini dikarenakan tingkat kepedulian keluarga pada pasien kurang dikarenakan beberapa faktor seperti tingkat pengetahuan yang kurang dikarenakan mayoritas keluarga pasien berpendidikan SD 39 orang atau 61,9\% dari sampel yang diambil dan kurangnya tingkat informasi yang terkait pengobatan.

\section{Kepatuhan Minum Obat}

Berdasarkan hasil penelitian yang didapatkan tingkat pasien patuh minum obat dari 63 responden didapatkan ratarata 28 responden $(44,4 \%)$ tidak patuh dalam menjalani program atau pengobatab dan 35 responden $(56,6 \%)$ pasien patuh minum obat selama pengobatan .dapat di simpulkan mayoritas pasien patuh minum obat dengan dukungan keluarga.

Penelitian yang dilakukan Berliana (2019) tentang faktor-faktor yang berhubungan dengan kepatuhan minum obat penderita tuberkulosis paru. Menyatakan dari 21 responden terdapat 8 orang $(38,1 \%)$ yang tidak patuh terhadap pengobatan, dan sedangkan 13 orang $(61,9 \%)$ yang patuh terhadap pengobatan tuberculosis paru. Sejalan dengan penelitian yang dilakukan oleh Idawaty S, (2019) menyatakan tingkat kepatuhan pasien minum obat dipengaruhi oleh dukungan dan motivasi dari keluarga dari 60 responden yang di uji dengan hasil dari 
uji chi-Square $p=0,002<0,05$ terdapat hubungan yang signifikan.

Kepatuhan pasien tuberkulosis dalam menjalani pengobatan merupak sikap atau rekasi seseorang terhadap tanggung jawab dan harus dijalani sesuai aturan (Fitri, 2018). Dapat disimpulkan bahwa tingkat kepatuhan pasien dalam minum obat sebanyak 56,6\% (35 orang) dari dari seluruh responden hal ini dikarenakan beberapa faktor salah satunya pasien mendapatkan informasi yang valid dan pemahaman tentang pengobatan Tuberkulosis paru dan juga ditandai dengan karaktersitik pekerjaan rata-rata karyawan swasta 22 orang dari 63 orang responden.

\section{Dukungan Keluarga dengan Tingkat Kepatuhan Minum Obat Pasien Tuberkulosis Paru}

Berdasarkan hasil penelitian yang dilakukan oleh peneliti dukungan keluarga memliki hubungan dnegna tingkat kepatuhan pasien dalam menjalani pengobatan di Rumah Sakit, hal ini berdasarkan hasil tabulasi silang yang dilakukan oleh peneliti didapatkan bahwa keluarga yang tidak mendukung dan pasien tidak patuh 33,5\% sedangkan tidak mendukung dengan patuh 22,2\%. Keluarga yang mendukung dengan pasien tidak patuh minum obat $11,1 \%$ dan dukungan keluarga dengan patuh minum obat $33,3 \%$.

Hasil uji Chi-Square juga didapatkan dengan nilai $p=0,010 \quad a=0,05$ yang dapat peneliti simpulkan terdapat dukungan keluarga berhubungan dengan tingkat kepatuhan pasien minum obat pada di Rumah Sakit. Sejalan dengan penelitian Fitri, LD. (2018) menyatakan bahwa salah satu faktor pasien patuh minum obat yaitu dengan adanya sikap dukungan keluarga dan motivasi hal ini dibuktikan dengan hasil ststistik signifikan $p=0,000 a=$ 0.05 .

Sikap dan tindakan penerimaan keluarga terhadap pasien yang menderita tuberculosis dengan memberikan pertolongan dan mendukung terhadap pengobatan pasien akan meningkatkan kepercayaan diri dan kesembuhan bagi pasien (Hendayani, 2016).

Motivasi yang diberikan oleh keluarga pada pasien yang mengalami tuberkulosis paru menjadi ujung tombak dalam meningkatkan kesembuhan pasien dan meningkatkan motivasi bagi pasien untuk sembuh. hal ini sejalan dengan penelitian yang dilakukan Muhardiani, (2015) mengatakan bahwa dukungan yang diberikan setiap keluarga terhadap pasien akan meningkatkan rasa percaya diri danmerasa dihargai sebagi keluarga.

Tingkat kepatuhan pasien tuberkulosis paru menjalani pengobatan secara teratur dipengaruhi oleh support dari keluarga yang akan meningkatkan motivasi pasien minum obat secara teratur hal ini baik untuk kesembuhan yang optimal. sejalan dengan penelitian yang Hendesa, A .(2017) menyatakan dukungan keluarga terhadap tingkat kepatuhan pasien minum obat saling berhubungan dnegan nilai signifikan $p=0,000 \quad(p<0,05) . \quad$ Peneliti menyimpulkan bahwa dengan adanya dukungan keluarga dapat meningkatkan motivasi pasien dalam menjalani pengobatan dan patuh dalam minum obat secara teratur. Hal ini juga dibuktikan dengan hasil uji yang telah dilakukan oleh peneliti yaitu nilai $C h i-$ Square $p=0,010$ dan nilai $a=0,05$. 


\section{SIMPULAN}

Setelah dilakukan analisis terhadap 63 responden yang menderita tuberkulosis paru sebagian besar keluarga yang tidak mendukung dari yang mendukung dan tingkat kepatuhan pasien minum obat tuberkulosis kurang. Terbukti dari hasil uji statistik menunjukkan adanya dukungan keluarga berhubungan secara signifikan dengan tingkat kepatuhan pasien tuberkulosis paru minum obat secara teratur di Rumah Sakit.

\section{DAFTAR PUSTAKA}

Aditama, TY. (2017).Tuberkulosis, Rokok Dan Perempuan. Jakarta: Balai Penerbit FKUI;

Afiani, D. (2019). Kepatuhan Obat Pada Pasien Tuberkulosis Paru Fase Intensif Pada Puskesmas Di Wilayah Sungai Raya. Jurnal Mahasiswa farmasi Kedookteran UNTAN Vol. 4, No 1 (2019)

Dinas Kesehatan Provinsi Sumatera Utara (Dinkes Provsu). (2018). Profil kesehatan Provinsi Sumatera Utara Tahun 2017. Diakses dari https://www.depkes.go.id/resourc es/download/profil/PROFIL_KES PROVI NSI_2017/02_Sumut_2017.pdf

Dinas Kesehatan Kota Medan. (2018). Pencapaian penanggulangan TB 2018 di Kota Medan. Anonim

Fitri, LD., Marlindawani, J., \& Purba, A.(2018). Kepatuhan Minum Obat Pada Pasien Tuberkulosis Paru. Jurnal Ilmu Kesehatahn Masyarakat Vol. 7 No 01

Handayani, E., Pujiastuti, W.(2016). Asuhan Holistik Masa Nifas dan Menyusui. 1st ed. YOGYAKARTA: Transmedika; 2016.
Hendesa, A., \& Tjekyan, RMS.(2017). Hubungan Pengetahuan, Sikap, Dan Dukungan Keluarga Dengan Kepatuhan Berobat Pada Pasien Tuberkulosis Paru Di RS Paru Kota Palembang Tahun 2017. Jurnal Kesehatan Vol. 5

Kemenkes RI. (2017). Hasil Riset Kesehatan Dasar Tahun 2017. Kementrian Kesehat RI. 2018;53(9):1689-99.

Lestari, T.,Saragih, L., \& Handian, F. (2021). Peran keluarga Berhubungan Dengan Kepatuhan minum Obat Klien Tuberkulosis. Jurnal Penelitian Perawat Profesional Vol 3 No. 2 27156885

Muhardiani, M. (2015). Hubungan Antara Dukungan Keluarga, Motivasi Dan Stigma Lingkungan Dengan Proses Kepatuhan Berobat Terhadap Penderita Tb Paru Di Wilayah Kerja Puskesmas Gang Sehat. Jurnal Mahasiswa dan Peneliti Kesehatan Vol 2, no. 3(2015)

Notoatmojo S. (2013) Metodologi Penelitian Kesehatan. 1st ed. Jakarta: Pt. Rineka Cipta; 2013.

Novi, B., \& Renny, H. (2019). FaktorFaktor Yang Berhubungan Dengan Kepatuhan Minum Obat Penderita Tb Paru Di Wilayah Kerja Puskesmas Nipah Panjang Tahun 2019. Jurnal Info Kesehatan Vol 10 No 1 (2020)

Pitters, TS., Kandou, GD., Nelwan, JE. (2018). Dukungan Keluarga Dalam Hubungannya Dengan Kepatuhan Minum Obat Pada Pasien Tuberculosis Paru Di Puskesmas Ranotana Weru. Kesmas. Jurnal KESMAS Vol. 7 
No. 5, 2018

Puspasari, SH. (2019) Asuhan Keperawatan Pada Pasien Dengan Gangguan Sistem Pernafasan. Yogyakarta: pustaka baru press; 2019. $352 \mathrm{p}$.

Rumimpunu, R., Maramis, FR., \& Kolibu, FK. (2018). Hubungan Antara Dukungan Keluarga Dan Dorongan Petugas Kesehatan Dengan Kepatuhan Berobat Penderita Tuberkulosis Paru Di Puskesmas Likupang Kabupaten Minahasa Utara. Jurnal KESMAS Vol. 7 No. 4, 2018

Rosa, F., \& Fujiati, I. (2020). Hubungan Dukungan Keluarga Terhadap Kepatuhan Minum Obat Anti Tuberkulosis (OAT) di UPT Puskesmas Teladan. Jurnal Ilmiah Maksitek Vol. 5 No.4 2655-4399

Siregar, I.,Siagian, P.,\& Effendy, E. (2019). Dukungan Keluarga Meningkatkan Kepatuhan Minum Obat pada Penderita Tuberkulosis paru di Kabupaten Tapanuli Utara. Jurnal Kedokteran Brawijaya vol 30 No. 4 pp.309-312

Sunarmin, S., Kurdaningsih, VS., \& Rizi, AP. (2020). Dukungan Keluarga dengan Kepatuhan Minum Obat pada Penderita Tb Paru. Jurnal Ilmiah Multi Science Kesehatan Vol. 12 No. 2 20878362

World Health Organization (2017). Global Tuberculosis. 2017;

World Health Organization, (2019). Global tuberculosis report 2019. Geneva, Switzerland. Diakses dari https://apps.who.int/iris/bitstream /handle/10665/329368/97892415 65714- eng.pdf?ua $=1$ 
Jurnal Penelitian Perawat Profesional, Volume 3 No 3 Hal 575 - 584, Agustus 2021 Global Health Science Group 